\title{
Sto lat polskiego handlu zagranicznego - uwarunkowania, najważniejsze trendy, partnerzy i produkty
}

\author{
One hundred years of Polish foreign trade. \\ Conditions, the most important trends, partners and products
}

This paper gives a short overview of one hundred years of Polish history in the area of trade on the occasion of the centenary of Poland regaining its independence. Four periods the interwar period, decades of the Polish People's Republic, the transition period from 1989 to 2004 and Polish membership in the European Union - are analysed to show that during these one hundred years, Poland had to build its trade and economy from scratch thrice. The paper focuses on the most important trends and looks into the geographic and product structures of trade. Unsurprisingly, the results show that the most dynamic growth and the most positive changes are observed in Polish trade during its membership in the European Union.

Keywords: trade, export, import, one hundred years of Poland's independence, interwar period, communist Poland, economic transformation, EU membership, trade balance, economic development, trade partners, geographical structure of trade, product structure of trade

Słowa kluczowe: handel, eksport, import, sto lat niepodległości Polski, dwudziestolecie międzywojenne, PRL, transformacja gospodarcza, członkostwo w UE, saldo handlowe, rozwój gospodarczy, partnerzy handlowi, struktura geograficzna handlu, struktura towarowa handlu

\section{Wprowadzenie}

Sto lat niepodległości Polski to dla handlu zagranicznego czas trudnych przemian i adaptacji. Dopiero ostatnie trzydziestolecie, a w szczególności czternaście lat członkostwa w Unii Europejskiej, stworzyło realne możliwości rozwoju wymiany zagranicznej. W omawianym czasie można wyróżnić cztery okresy historyczne, których cezurę za każdym razem stanowiły głębokie zmiany ustrojowe: II RP i odbudowa państwa polskiego w latach 1918-1939; Polska Ludowa i ograniczone możliwości handlu z państwami spoza bloku 
wschodniego (1945-1989) ${ }^{1}$; okres transformacji gospodarczej i pierwszych lat III RP (1989-2004); członkostwo w UE, które spowodowało zmianę podmiotowości Polski w dziedzinie handlu zagranicznego na arenie międzynarodowej i przyniosło jego dalszy rozwój (2004-2018).

Niniejszy zarys historii polskiego handlu zagranicznego powstał głównie w związku z setną rocznicą odzyskania przez Polskę niepodległości i z uwagi na dotychczasowe badania tego tematu tylko częściowo jest studium oryginalnym. Najpełniejsze jest opracowanie Leszka Jerzego Jasińskiego pod tytułem Blizej centrum czy na peryferiach? Polskie kontakty gospodarcze z zagranica $w X X$ wieku. Ze względu na datę publikacji obejmuje ono jednak tylko pierwsze lata członkostwa Polski w UE, dlatego w niniejszym artykule perspektywa ta została rozszerzona.

\section{W cieniu zaborów, wojen i kryzysu (1918-1939)}

Polityka handlowa dwudziestolecia międzywojennego nieustannie musiała stawiać czoła wyzwaniom o charakterze zarówno zewnętrznym, międzynarodowym, jak i wewnętrznym, krajowym. Kres kształtowania się terytorium Polski wyznaczył dopiero rok 1923, co nie pozostawało bez wpływu na możliwości zarządzania państwem i scalanie ziem pod kątem gospodarczym, a zatem na ekonomiczny potencjał II RP². Należy podkreślić, że trwające do 1921 r. działania wojenne siłą rzeczy stawiały przed odradzającym się państwem polskim inne priorytety niż kwestie gospodarcze. Tuż po odzyskaniu niepodległości posługiwano się różnymi walutami, a handel nimi był ograniczony.

Na podstawie dekretu naczelnika państwa z 1919 r. handel zagraniczny i tranzyt podlegały reglamentacji; na obrót handlowy konieczne było otrzymanie pozwoleń, choć dopuszczano wyjątki od tej reguły. Egzekwowaniem przepisów zajmowały się Główny Urząd Przywozu i Wywozu, związane z poszczególnymi branżami izby handlowe oraz okręgowe urzędy dla branż nieobjętych w izbach. Taka polityka Ministerstwa Przemysłu i Handlu zakończyła

1 Nazwa Polska Rzeczpospolita Ludowa (PRL) oficjalnie funkcjonowała dopiero od 1952 r. Chodzi tu jednak zarówno o lata 1952-1989, jak i wcześniejsze (1944-1952), gdy oficjalna nazwa państwa wciąż brzmiała Rzeczpospolita Polska.

$2 \quad$ 15.03.1923 r. Rada Ambasadorów zaakceptowała przynależność Wileńszczyzny i Małopolski Wschodniej do Polski. Zob. L.J. Jasiński, Bliżej centrum czy na peryferiach? Polskie kontakty gospodarcze z zagranica w XX wieku, Warszawa 2011, s. 73. 
się dopiero w roku 1924. W 1936 r. wprowadzono natomiast ograniczenia importu towarów objętych przywozową taryfą celną, a także wymogi uzyskania na to zgody, która często warunkowana była dokonaniem innej transakcji ${ }^{3}$.

Lata 1923-1924 to zmagania z hiperinflacją. Problemowi zaradziły dopiero działania rządu Władysława Grabskiego, który wpierw zrównoważył budżet, a następnie w 1924 r. przeprowadził reformę walutową, wprowadzając do obiegu polskiego złotego, emitowanego przez nowo utworzony Bank Polski. Kurs ustabilizował się, ale w związku ze spadkiem ceny surowców i towarów eksportowanych przez Polskę (skór, drewna, węgla i cukru) wystąpił deficyt handlowy, a dodatkowo klęska nieurodzaju zmniejszyła możliwości eksportowe w sektorze rolnym. Deprecjacja złotego wynikała z ponownego pojawiania się deficytu budżetowego, wzrostu podaży pieniądza o niskim nominale oraz niewystarczających do obrony waluty rezerw Banku Polskiego ${ }^{4}$.

Powyższe uwarunkowania stanowiły dla handlu poważne przeszkody, w związku z czym interesujące nas dane statystyczne dostępne są dla okresu od roku 1922. Warto zwrócić uwagę na powolny wzrost wolumenu polskiej wymiany w latach 1922-1929. Eksport nieprzerwanie zwiększał się aż do 1929 r., kiedy osiągnął najwyższą wartość - 2,8 mln zł, dwuipółkrotnie większą niż w roku 1922. Import natomiast silniej odczuł skutki wojny handlowej z Niemcami, w wyniku której w 1926 r. jego wartość spadła niemalże o połowę, ciągnąc za sobą jednocześnie zmniejszenie łącznego wolumenu obrotów o 23\%. W latach 1927-1928 nastąpiło ponowne odbicie, a sprowadzane towary osiągnęły maksymalną w dwudziestoleciu wartość $3,4 \mathrm{mln}$ zł (210\% wartości z 1922 r.). Łączna wymiana handlowa zanotowała rekordowy poziom w 1929 r. - 5924 mln zł. Wielki kryzys, który nastąpił tuż potem, przekreślił szanse rozwoju polskiego handlu i rozpoczął okres pięciu lat spadków wartości wymiany handlowej, która na koniec 1935 r. była niższa niż w roku 1922. Chociaż od 1935 r. zarówno eksport, jak i import zaczęły ponownie rosnać, to na koniec 1938 r. - ostatniego pełnego roku przed wybuchem drugiej wojny światowej - nie przekroczyły wartości z 1922. Warto zwrócić uwagę, że saldo wymiany handlowej Polski było dodatnie w latach niekorzystnej koniunktury gospodarczej - m.in. w roku 1923, 1926 czy latach 1930-1936.

3 Tamże, s. 82-86.

4 Tamże, s. 88-95. 


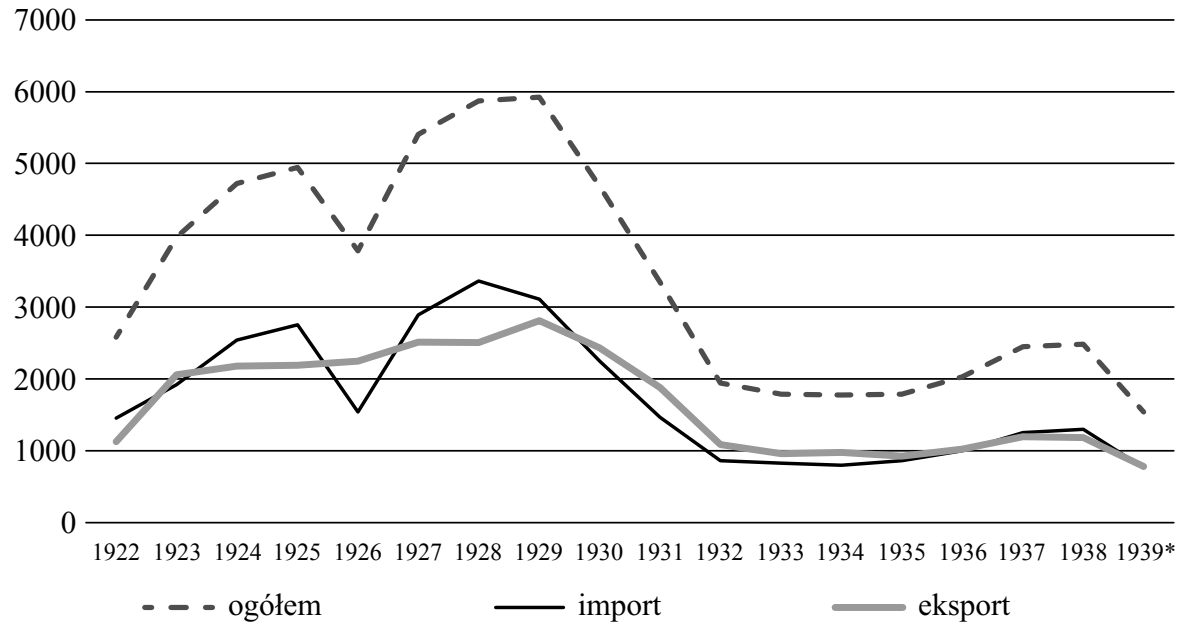

\section{Wykres 1. Obroty handlowe Polski w latach 1922-1939 (w mln zl)}

* Dane za niepełny rok ze względu na wybuch wojny.

Źródło: Zarys historii Polski w liczbach. Społeczeństwo, gospodarka, oprac. C. Kuklo, J. Łukasiewicz, C. Leszczyńska, Warszawa 2012

Eksport stanowił w 1929 r. 11\% dochodu narodowego Polski i dotyczył $25 \%$ produkcji przemysłowej, dlatego też jego spadek miał istotny wpływ na kondycję całej gospodarki ${ }^{5}$. Wywożone z kraju produkty - w 1929 r. 60\% eksportu stanowiły paliwa, surowce i materiały (półfabrykaty) - były ściśle związane z polską aktywnością ekonomiczną na terenie innych państw. Za 34\% eksportu odpowiadały produkty rolno-spożywcze. Mała liczba dóbr przemysłowych i konsumpcyjnych wśród towarów sprzedawanych za granicę wskazuje na wyjątkowo słabo rozwiniętą gospodarkę. Znaczący udział produktów rolno-spożywczych świadczy, że Polska była istotnym wytwórcą w tym sektorze ${ }^{6}$. Dość powiedzieć, że w latach 1934-1938 odpowiadała za 15,4\% światowej produkcji ziemniaków, $14 \%$ żyta oraz $4 \%$ owsa i jęczmienia 7 .

Kryzys gospodarczy i spadek obrotów doprowadziły do zmiany najważniejszych partnerów handlowych Polski, w tym do ograniczenia roli dawnych państw zaborczych. Jeszcze w 1929 r. ponad połowa wywożonych z kraju towarów trafiała do Niemiec (31,2\%), Czechosłowacji i Austrii (po 10,5\%).

5 Tamże, s. 100-101.

6 Z. Landau, J. Tomaszewski, Zarys historii gospodarczej Polski 1918-1939, Warszawa 1960.

7 Ciż, Trudna niepodległość. Rozważania o gospodarce Polski 1918-1939, Warszawa 1968, s. 118.

8 L.J. Jasiński, Bliżej centrum..., s. 105. 
Znajdowanie nowych rynków zbytu napotykało trudności, więc w celu wsparcia tego procesu eksportowano towary po cenach dumpingowych (tak aby w zamian zapewnić sobie zaopatrzenie w surowce i maszyny) ${ }^{9}$. Struktura geograficzna eksportu uległa w końcu zmianie i w 1938 r. najważniejszym rynkiem stała się Wielka Brytania (18,2\%), przed Niemcami $(14,5 \%)$ oraz Szwecją $(6 \%)^{10}$. Do spadku pozycji Niemiec przyczyniła się m.in. wojna celna. W czerwcu 1925 r. zakazały one importu węgla z Polski do czasu zawarcia traktatu handlowego, na co Warszawa odpowiedziała analogicznym zakazem w stosunku do innych produktów. Wartość towarów, na które Niemcy nałożyły bariery handlowe, stanowiła 56,6\% wcześniejszego polskiego eksportu do tego kraju, czyli $26,75 \%$ całego wywozu z Polski, ale zaledwie $1,78 \%$ niemieckiego importu. Polskie embarga dotknęły $46,88 \%$ niemieckiego eksportu nad Wisłę, co przekładało się zaledwie na 3,3\% niemieckiego wywozu ogółem. Konflikt trwał do 1934 r. i osłabił potencjał handlowy państwa polskiego ${ }^{11}$.

ZSRR odgrywał w polskiej wymianie handlowej dwudziestolecia międzywojennego rolę ograniczoną: w 1928 r. wartość towarów sprzedawanych do tego państwa stanowiła 1,5\% całkowitego eksportu Polski, importowanych zaś $-1,2 \%$. Powodem takiego stanu rzeczy była przede wszystkim zmiana ustrojowa w Rosji oraz m.in. niedopasowanie partnerów - ZSRR importował przede wszystkim artykuły do celów inwestycyjnych, a eksportował produkty spożywcze, surowce i futra. Polska mogła eksportować tam głównie wyroby przemysłowe (wcześniej Królestwo Kongresowe było np. znaczącym eksporterem wyrobów włókienniczych do Rosji), jednak po rewolucji październikowej autarkiczny charakter państwa uniemożliwił przywrócenie znaczenia tej wymiany ${ }^{12}$.

\section{Polska Ludowa (1945-1989)}

Po drugiej wojnie światowej polski handel międzynarodowy ponownie znalazł się w punkcie zerowym. Przez sześć lat wojny Polska straciła ponad $16 \%$ ludności, a jej terytorium uległo znacznym przeobrażeniom. Maszyny przemysłowe zostały zniszczone (podobnie jak cała infrastruktura) bądź wywiezione. Przede wszystkim jednak zmieniły się najbardziej podstawowe

9 Z. Landau, J. Tomaszewski, Trudna niepodległość..., s. 127-130.

10 L.J. Jasiński, Bliżej centrum..., s. 105.

11 Z Landau, J. Tomaszewski, Zarys..., s. 90-93.

12 Ciż, Trudna niepodlegtość..., s. 127-130; L.J. Jasiński, Bliżej centrum..., s. 106-111. 
zasady funkcjonowania gospodarki - zlikwidowano wolny rynek i konkurencję, zastępując je centralnym planowaniem. To władza centralna miała odtąd odgórnie zapewniać równowagę $\mathrm{w}$ gospodarce, arbitralnie ustalając ceny i myśląc przede wszystkim o środkach produkcji. Eksport pełnił rolę drugorzędną wobec importu, którego wielkość planowano poprzez określenie zapotrzebowania na sprowadzane towary. Planowanie handlu uwzględniało wydawanie koncesji na prowadzenie wymiany z zagranicą. Przygotowywane przez państwo pięcioletnie plany rozwoju gospodarczego często odbiegały jednak od rzeczywistego poziomu eksportu i importu - średnio o odpowiednio 10 i $17 \%$. Z powyższych powodów, a także m.in. w związku z dyktowaniem innych cen na towary przeznaczone do obrotu $\mathrm{z}$ zagranicą i na rynek krajowy, marginalną wagą ceł czy brakiem wymienialnej waluty tradycyjne narzędzia polityki handlowej były bardzo ograniczone ${ }^{13}$.

Handel zagraniczny w Polsce Ludowej został całkowicie podporządkowany polityce, i to zarówno centralnemu planowaniu, jak i interesom sojuszy państw komunistycznych - jedynych, z którymi dozwolona była wymiana. Od 1949 r. Polska była członkiem Rady Wzajemnej Pomocy Gospodarczej, która miała administrować wymianą handlową państw bloku wschodniego i prowadzić rozliczenia finansowe, do czego w 1964 r. powołano nową instytucję - Międzynarodowy Bank Współpracy Gospodarczej - oraz nową walutę wykorzystywaną jedynie na płaszczyźnie międzypaństwowej wymiany handlowej, tzn. rubla transferowego. Relacje gospodarcze z państwami Zachodu były bardzo okrojone, a one same też ograniczały eksport niektórych towarów ze względu na ich strategiczne znaczenie (wojskowe, technologiczne itd.), nie udzielały państwom bloku komunistycznego kredytów eksportowych, a na import ze Wschodu nakładały $\mathrm{cła}^{14}$.

Pierwsze lata po wojnie odznaczały się gwałtownym wzrostem obrotów polskiego handlu zagranicznego - od zera niemal do poziomu z roku 1929. Struktura wymiany była podobna do przedwojennej: przeważały surowce (ponad $60 \%$ obrotów), a na drugim miejscu plasowała się żywność, choć z o połowę niższym udziałem. Dominującym partnerem handlowym Polski Ludowej był Związek Radziecki, chociaż do 1949 r. jego znaczenie malało, a rosła rola niektórych państw zachodnich, m.in. Szwecji i Stanów Zjednoczonych. Trendy te przerwało jednak zaprowadzenie w Polsce reżimu stalinowskiego. Warto zaznaczyć, że narzucone ceny eksportowanego do ZSRR węgla

13 Tamże, s. 165-172.

14 Tamże, s. 174-181. 
i koksu - wielokrotnie niższe niż rynkowe - odbijały się na wartości polskiego eksportu, a straty z tego tytułu sięgnęły $630 \mathrm{mln}$ dol. ${ }^{15}$ Wraz ze zwiększeniem roli centralnego planowania i zamykaniem się na Zachód celem gospodarczym stało się uniezależnienie od zewnętrznych partnerów handlowych. Nie przerwało to tendencji wzrostowych eksportu, który w latach 1949-1955 zwiększył się o $30 \%$, oraz importu, który wzrósł o $60 \%$. Wartości te były jednak nieproporcjonalne do wzrostu PKB, wynoszącego dla tego okresu 74\%. Wzrosło też wówczas znaczenie bloku socjalistycznego wśród polskich partnerów handlowych -z $44 \%$ do $64 \%{ }^{16}$. W strukturze towarowej widoczne były niewielkie przesunięcia, ale nieustannie dominującą rolę w eksporcie i imporcie odgrywały surowce. Wśród towarów importowanych sukcesywnie rósł udział maszyn, urządzeń i żywności.

Po 1955 r. w polskim handlu zagranicznym wciąż odnotowywany był wzrost obrotów, ale ponownie coraz większą rolę zaczęły odgrywać w nim państwa zachodnie, m.in. dzięki przekazywanej PRL pomocy kredytowej. Udział ZSRR w wymianie handlowej Polski spadł w 1958 r. do wyjątkowo niskiego poziomu $27 \%$ w przypadku importu i $25 \%$ w eksporcie. Odtąd jednak w polskim handlu zagranicznym ponownie zaczęło maleć znaczenie państw spoza bloku socjalistycznego, choć nominalna wartość wymiany wciąż wykazywała tendencję rosnącą. Wahania te wiązały się zarówno z próbami popaździernikowych korekt czynionymi przez polskie władze (m.in. zaniechaniem forsownej industrializacji), jak i np. z zaufaniem USA, które zdecydowały się udzielić komunistycznej gospodarce kredytu. Nie doszło jednak do systemowej przebudowy polskiego handlu zagranicznego. W latach sześćdziesiątych nastąpił gwałtowny wzrost obrotów (trzykrotny w latach 1960-1970) i ponownie większą rolę odgrywał blok socjalistyczny; podczas gdy w latach pięćdziesiątych państwa zachodnie miały $40 \%$ udziału w obrotach polskiego handlu, to w sześćdziesiątych spadł on do $36 \%$, a w siedemdziesiątych - do $34 \%{ }^{17}$.

W porównaniu do lat pięćdziesiątych w kolejnych dekadach nastąpiła rewolucja w strukturze obrotów handlowych Polski. Udział surowców energetycznych spadł w 1960 r. do 23\%, a w 1970 r. - do zaledwie 12,5\%; wyroby przemysłowe stanowiły $73 \%$ polskiego handlu zagranicznego w 1960 r. i $81 \%$ dekadę później. Analogiczne zmiany zaszły w imporcie. Początkowo import żywności znacznie wzrósł, ale poprzez m.in. odgórne ograniczenia trend ten

15 J. Kaliński, Gospodarka w PRL, Warszawa 2012, s. 71.

16 Tamże, s. 74.

17 Obliczenia własne na podstawie: Zarys historii Polski w liczbach. Społeczeństwo, gospodarka, oprac. C. Kuklo, J. Łukasiewicz, C. Leszczyńska, Warszawa 2012, s. 473. 
udało się odwrócić: import produktów z tego sektora zmalał o połowę i nieznacznie wzrosła wartość ich eksportu ${ }^{18}$.

Lata siedemdziesiąte $\mathrm{w}$ historii polskiego handlu zagranicznego to okres szczególny. Nie przeprowadzono wówczas co prawda żadnych głębokich reform strukturalnych, ale w celu zyskania większej społecznej akceptacji dla systemu komunistycznego podjęto decyzje sprzyjające wzrostowi konsumpcji (m.in. poprzez zamrożenie cen niektórych dóbr rolno-spożywczych), co z kolei zmuszało do zwiększenia importu surowców. Chociaż do większego otwarcia się Polski Ludowej (m.in. na zachodnią myśl technologiczną) doszło już wcześniej, to właśnie okres rządów Edwarda Gierka charakteryzował się ogromnym wzrostem dynamiki obrotów handlowych napędzanych zagranicznymi kredytami. Rozwój handlu zagranicznego ułatwiło też uzyskanie przez Polskę pełnego członkostwa w Układzie Ogólnym w Sprawie Ceł i Handlu (GATT) jeszcze w $1967 \mathrm{r}$.

Łączne obroty handlowe w cenach bieżących wzrosły w tamtej dekadzie niemalże czterokrotnie. W szczególności dotyczyło to polskiego importu, gdyż między 1970 a 1980 r. wartość towarów sprowadzonych z państw zachodnich zwiększyła się pięciokrotnie ${ }^{19}$. W cenach stałych wzrost ten nadal był imponujący i przekroczył $120 \%$ dla importu i $110 \%$ dla eksportu ${ }^{20}$. Co ciekawe, w eksporcie najpierw można było zaobserwować ponowne zwiększenie roli surowców (do 20\% w 1975 r.), a potem sukcesywny spadek (do 14\% w 1980 r.). Udział wyrobów przemysłowych w polskim eksporcie po chwilowym spadku wrócił w 1980 r. do poziomu ok. 80\%.

W strukturze geograficznej polskiego handlu widoczne było otwarcie na Zachód, szczególnie w imporcie, gdzie w 1975 r. udział państw kapitalistycznych był nawet większy niż członków RWPG (49\% wobec 44\%). Do 1980 r. wróciła ona jednak do poprzedniego kształtu, choć widoczne były przesunięcia na rzecz wymiany z państwami zachodnimi - zarówno eksport, jak i import zaczęły się koncentrować na państwach Europejskiej Wspólnoty Gospodarczej (EWG) ${ }^{21}$.

Koniec lat siedemdziesiątych był zwieńczeniem trzydziestoletniego okresu wzrostu gospodarczego i związanego z tym rozwoju handlu zagranicznego. W latach osiemdziesiątych poziom polskiej wymiany spadł jednak do wartości z początku poprzedniej dekady. Wprowadzenie stanu wojennego skutkowało

18 L.J. Jasiński, Bliżej centrum..., s. 232-233.

19 Zarys historii..., s. 473.

20100 lat Polski w liczbach. 1918-2018, Warszawa 2018, s. 74.

21 L.J. Jasiński, Blizej centrum..., s. 258-259, 256-257, 254-255. 
nałożeniem przez kraje Wspólnoty Europejskiej i Stany Zjednoczone sankcji gospodarczych, co znacząco wpłynęło na ograniczenie handlu zagranicznego. Ponownie zwiększyło się w tej dekadzie znaczenie państw bloku socjalistycznego, szczególnie ZSRR. Eksport do tego obszaru wzrósł w ujęciu realnym o 46\%, a import - o 9\%. Szczególnie wysoki był wzrost eksportu węgla kamiennego do ZSRR, który w 1984 r. osiągnął rekordowy wolumen $43 \mathrm{mln}$ ton. Dla handlu z państwami zachodnimi tendencje te nie były korzystne; zatrzymanie spadku obrotów nastąpiło dopiero w połowie dekady, a w 1989 r. wartość eksportu i importu była na poziomie około $50 \%$ rekordowych statystyk z końca lat siedemdziesiątych Ograniczenie handlu zagranicznego wpłynęło natomiast na poprawę bilansu; od 1982 r. saldo obrotów handlowych Polski zaczęło być dodatnie.

Reformy gospodarcze $\mathrm{z}$ drugiej połowy lat osiemdziesiątych ukierunkowane były m.in. na rozszerzenie możliwości prowadzenia działalności handlowej z zagranicą, stąd np. zlikwidowano złotego dewizowego i zaczęto ustalać kurs polskiej waluty względem dolara. W 1988 r. wartość handlu z państwami zachodnimi ponownie stała się większa niż z członkami RWPG.

\section{Okres transformacji ustrojowej (1989-2004)}

Rok 1989 w oczywisty sposób wyznacza kolejną istotną cezurę w historii polskiego handlu zagranicznego. Transformacja gospodarcza kraju oraz polityka zmierzająca do zawiązania nowych aliansów polityczno-gospodarczych bardzo silnie wpływały na wahania eksportu i importu w latach 1990-2004. Przeobrażenia dotykały niemal każdej dziedziny - od decentralizacji gospodarki i dopuszczenia sektora prywatnego do obrotów z zagranicą, przez nowe taryfy celne, reformy walutowe, umożliwienie wymiany dewiz i wyznaczania kursu walut, po negocjowanie umów z byłymi państwami ZSRR oraz renegocjację GATT. Dążąc do akcesji do Wspólnot Europejskich, Polska liberalizowała handel zagraniczny z państwami regionu, które również ubiegały się o członkostwo (warto tu wspomnieć o stworzeniu CEFTA), oraz z samą późniejszą UE.

Konieczność nadrabiania strat rozwojowych powodowała ujemne saldo handlowe (poza rokiem 1990, kiedy doszło do dewaluacji złotego). Nominalnie eksport wzrósł w latach 1990-2000 dziesięciokrotnie, a import dwudziestokrotnie; realnie zaś - odpowiednio o 501\% i 295\%. W latach 1991-1993 doszło do załamania eksportu, co było skutkiem przeprowadzanych zmian, a także utraty dotychczasowych rynków zbytu w dawnym bloku sowieckim. Chociaż liberalizacja handlu dotyczyła także partnerów na Wschodzie, to jednak w latach 1989-2004 dokonała się zdecydowana 
zmiana w strukturze geograficznej polskiego handlu - udział Europejskiej Wspólnoty Gospodarczej (przekształconej następnie w UE) w eksporcie i imporcie III Rzeczypospolitej wzrósł odpowiednio z 32\% do 79\% oraz z 34\% do $68 \%$, czyli ponad dwukrotnie. Dane te potwierdzają dotychczasowe badania, które wskazywały, że ze względu na umowy liberalizujące wzajemny handel i zapewniające dostęp do rynku wewnętrznego efekty integracyjne w postaci wzrostu wymiany dóbr i usług między Polską a państwami członkowskimi UE występowały na dużą skalę jeszcze przed akcesją Polski ${ }^{22}$.

Głównym partnerem gospodarczym Rzeczypospolitej stały się w tym czasie Niemcy, wyprzedzając państwa RWPG ${ }^{23}$ już w 1991 r. Choć ZSRR plasował się jeszcze wówczas pod tym względem na drugim miejscu, a Wielka Brytania na trzecim, to już w 1995 r. Rosja stała się dopiero trzecim partnerem handlowym Polski, ustępując w jej eksporcie Holandii, a w imporcie Włochom. W 2000 r. Italia stała się drugim krajem dla polskiego eksportu, przed Francją. Ponownie wzrósł natomiast udział Rosji w polskim imporcie, już tylko nieznacznie wyprzedzanej wtedy przez Włochy.

W okresie transformacji ustrojowej widoczne były również zmiany w strukturze towarowej polskiej wymiany handlowej. Rola żywności, paliw i surowców zaczęła maleć, rósł natomiast udział produktów przemysłowych, zarówno elektromechanicznych (szczególnie z branży samochodowej), jak i tekstylnych czy drzewno-papierniczych. Bardzo wolno przebiegała natomiast transformacja w segmencie usług. Ze względu na zacofanie tego sektora $\mathrm{w}$ Polsce największą rolę odgrywały początkowo usługi transportowe i turystyczne, których znaczenie z czasem powoli malało na rzecz łącznościowych, informatycznych czy biznesowych ${ }^{24}$.

\section{Okres stabilizacji - czlonkostwo w UE}

W latach 2004-2016 nie było znaczących zmian w strukturze geograficznej polskiego handlu, dla którego kluczowym regionem niezmiennie pozostaje Unia Europejska. Chociaż w latach 2004-2012 udział państw rozwiniętych w polskim handlu zagranicznym spadł z 80,2\% do 73,1\% (a obszaru

22 A. Szypulewska-Porczyńska, Rozwój handlu zagranicznego Polski po wstapieniu do Unii Europejskiej, [w:] Wybrane aspekty funkcjonowania Polski w Unii Europejskiej. Bilans dziesięciu lat członkostwa, red. G. Wojtkowska-Łodej, H. Bąk, Warszawa 2014, s. 119.

23 J. Kaliński, Transformacja gospodarki polskiej w latach 1989-2004, Warszawa 2009, s. $118-121$.

24 Tamże, s. 120-121. 
UE z 73,3\% do 66,5\%), to jednak po 2012 r. ponownie rósł - do 77,4\% w 2016 r. w przypadku państw rozwiniętych i 70,6\% jeżeli chodzi o samą UE. Zmiany warunkowane były przede wszystkim początkowym wzrostem znaczenia państw rozwijających się w polskiej wymianie handlowej (skok z 10,3\% do 16,3\% w latach 2004-2016) oraz wahaniami w handlu z krajami Europy Środkowo-Wschodniej (EŚW). W latach 2004-2012 obroty z tymi ostatnimi zwiększyły się z 9,5\% do 12,9\%, natomiast w latach 2012-2016 spadły o połowę - z $12,9 \%$ do $6,3 \%{ }^{25}$. Główną przyczyną tego spadku był prawdopodobnie konflikt na Ukrainie i sankcje nałożone przez UE na Rosję oraz rosyjskie embargo na produkty rolne.

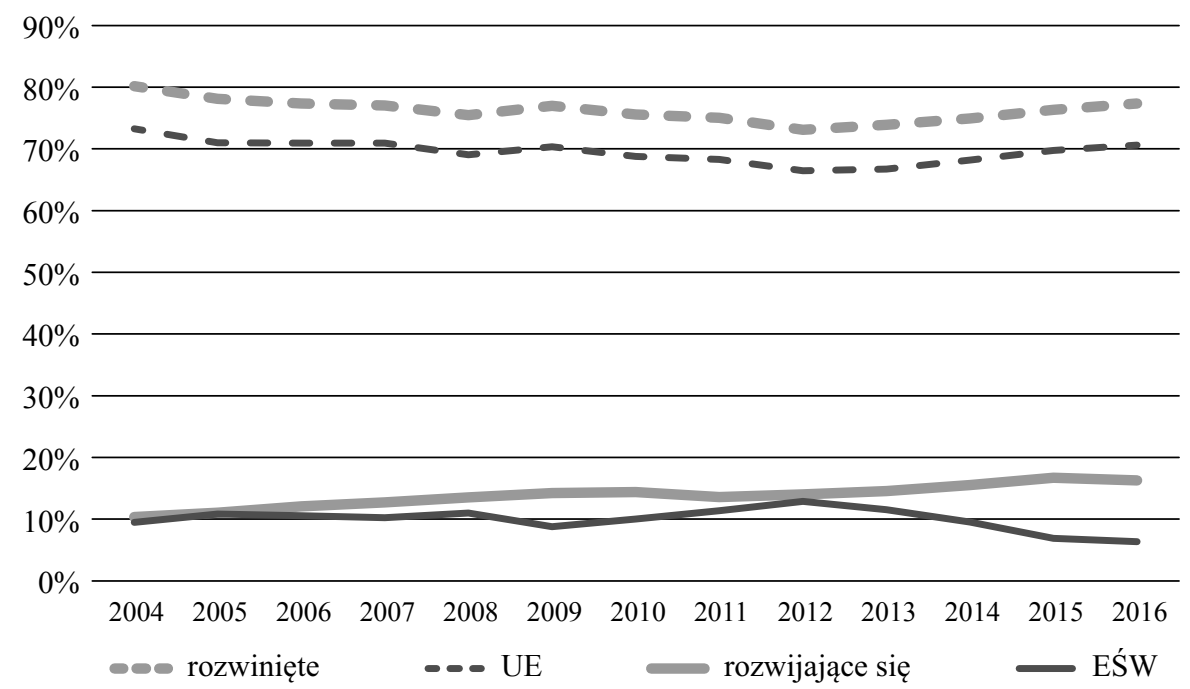

Wykres 2. Udzial poszczególnych grup państw w obrotach handlowych Polski w latach 2004-2016

Źródło: „Rocznik Statystyczny Handlu Zagranicznego” 2008, 2013, 2017, obliczenia własne

Tej ogromnej zmianie w polskiej gospodarce warto przyjrzeć się również $\mathrm{w}$ rozbiciu na eksport oraz import, ponieważ w tym pierwszym dynamika zmian była o wiele niższa. Po dwunastu latach od przystąpienia do UE udział zrzeszonych w niej państw w polskim eksporcie zwiększył się po okresowych spadkach do rekordowego poziomu 79,8\% (o $0,6 \%$ względem 2004 r.), udział państw rozwijających się wzrósł natomiast zaledwie o 2,5\% (do 8,2\%), a o 3,5\% spadł udział państw EŚW. Wynika z tego, że transformacja

25 „Rocznik Statystyczny Handlu Zagranicznego” 2008, 2013, 2017. 
geograficzna handlu w latach 2004-2016 napędzana była w znacznym stopniu przez zmiany w imporcie. XXI w. przyniósł spadek znaczenia UE jako dostawcy towarów do Polski; udział państw członkowskich w jej imporcie zmalał z $68,3 \%$ do $61,2 \%$. Nieznacznie spadło też pod tym względem znaczenie EŚS (z 9,9\% do 7,2\%), choć do 2012 r. udział tego regionu wzrastał do $15,9 \%$. O 10,4\% zwiększył się natomiast udział wartości towarów sprowadzanych do Polski z państw rozwijających się, zwłaszcza surowców ${ }^{26}$.

Niezmiennie najważniejszym partnerem handlowym Polski były w latach 2004-2016 Niemcy. Zmiany następowały natomiast na miejscu drugim. Jeszcze w 2005 i 2010 r. drugim z największych partnerów polskiego importu była Rosja (eksporter przede wszystkim ropy naftowej i gazu ziemnego), ale w 2014 r. na trzecie miejsce zepchnęły ją Chiny (eksporter towarów przemysłowych). Wśród partnerów polskiego eksportu trzy czołowe miejsca zajmują państwa członkowskie UE: w 2005 r. na drugim i trzecim plasowały się odpowiednio Francja i Włochy, a w 2010 r. - Francja i Wielka Brytania. W 2011 r. Francja wypadła z grupy trzech głównych partnerów polskiego eksportu, ustępując miejsca Wielkiej Brytanii i Czechom. Na pozaeuropejskich kierunkach eksportowych najważniejszymi partnerami handlowymi Polski w 2016 r. były Stany Zjednoczone (2,3\%) oraz Chiny $(0,9 \%)$; sytuacja nie uległa więc znacznym zmianom w porównaniu z rokiem 2007 r., gdy wskaźniki te wynosily odpowiednio $1,5 \%$ i $0,7 \%$.

Również w handlu usługami najważniejszym dla Polski regionem pozostaje Unia Europejska, która w 2016 r. odpowiadała za 72\% polskich obrotów w tym sektorze. W przeciwieństwie do handlu towarowego większy udział odnotowano jednak wówczas w ich imporcie z UE (77\%) niż w eksporcie do krajów członkowskich (70\%). Najważniejszym pozaunijnym partnerem Polski w handlu usługami była w 2016 r. Szwajcaria, z udziałem rzędu 7\% (5\% polskiego importu i 9\% eksportu), a pozaeuropejskim - Stany Zjednoczone (odpowiednio 5\% i 6\%). Inne kraje spoza UE, których udział w polskim handlu usługami wynosił przynajmniej $1 \%$, to Rosja $(2 \%)$ oraz Norwegia, Chiny i Kanada (po 1\%) ${ }^{27}$. Potwierdzają to dotychczasowe dane, które wykazywały stosunkowo niską dynamikę przemian struktury geograficznej handlu w tym sektorze po akcesji Polski do UE ${ }^{28}$.

26 „Rocznik Statystyczny Handlu Zagranicznego” 2008, 2013, 2017, obliczenia własne.

27 „Rocznik Statystyczny Handlu Zagranicznego” 2017.

28 K. Kłosiński, T. Rozumowska-Gapeeva, Międzynarodowy obrót ustugowy Polski (20042007), [w:] Polska w handlu międzynarodowym. Materiaty z konferencji naukowej z okazji 70. rocznicy urodzin profesora Pawta Bożyka, red. J. Misala, Warszawa 2011, s. 143. 
Dla roku 2016 można wyróżnić trzynaście grup produktów ${ }^{29}$, które miały przynajmniej 2\% udziału w strukturze towarowej polskiego eksportu (tabela 1).

\section{Tabela 1. Produkty o przynajmniej dwuprocentowym udziale w polskim eksporcie w 2016 r. ${ }^{30}$}

\begin{tabular}{|l|c|c|}
\hline \multicolumn{1}{|c|}{ Grupa produktów (wg klasyfikacji CN) } & Eksport & Import \\
\hline $\begin{array}{l}\text { maszyny i urządzenia mechaniczne; sprzęt elektryczny; ich części; } \\
\text { urządzenia do rejestracji i odtwarzania dźwięku i obrazu oraz części } \\
\text { i wyposażenie do tych artykułów }\end{array}$ & $25 \%$ & $25 \%$ \\
\hline $\begin{array}{l}\text { pojazdy, statki powietrzne, jednostki pływające oraz współdziałające } \\
\text { urządzenia transportowe }\end{array}$ & $15 \%$ & $12 \%$ \\
\hline metale nieszlachetne i artykuły z metali nieszlachetnych & $9 \%$ & $10 \%$ \\
\hline produkty przemysłu chemicznego & $7 \%$ & $10 \%$ \\
\hline $\begin{array}{l}\text { tworzywa sztuczne i artykuły z tworzyw sztucznych, kauczuk } \\
\text { i artykuły z kauczuku }\end{array}$ & $7 \%$ & $8 \%$ \\
\hline artykuły przemysłowe różne & $7 \%$ & $3 \%$ \\
\hline $\begin{array}{l}\text { gotowe artykuły spożywcze (napoje bezalkoholowe, alkoholowe } \\
\text { i ocet, tytoń i przemysłowe namiastki tytoniu) }\end{array}$ & $6 \%$ & $4 \%$ \\
\hline zwierzęta żywe; produkty pochodzenia zwierzęcego & $4 \%$ & $3 \%$ \\
\hline materiały i artykuły włókiennicze & $4 \%$ & $5 \%$ \\
\hline produkty mineralne & $3 \%$ & $7 \%$ \\
\hline $\begin{array}{l}\text { ścier z drewna lub pozostałego włóknistego materiału celulozowego; } \\
\text { papier lub tektura z odzysku (makulatura i odpady); papier i tektura } \\
\text { oraz artykuły z papieru i tektury }\end{array}$ & $3 \%$ & $3 \%$ \\
\hline produkty pochodzenia roślinnego & $2 \%$ & $2 \%$ \\
\hline $\begin{array}{l}\text { drewno i artykuły z drewna; węgiel drzewny; korek i artykuły } \\
\text { z korka; wyroby ze słomy, z esparto lub innych materiałów } \\
\text { do wyplatania; wyroby koszykarskie i z wikliny }\end{array}$ & $2 \%$ & $1 \%$ \\
\hline $\begin{array}{l}\text { przyrządy i aparatura optyczna, fotograficzna, kinematograficzna, } \\
\text { pomiarowa, kontrolna, precyzyjna, medyczna lub chirurgiczna; zegary } \\
\text { i zegarki; instrumenty muzyczne; części i akcesoria do powyższych }\end{array}$ & $2 \%$ & $2 \%$ \\
\hline
\end{tabular}

Źródło: oprac. własne na podstawie danych GUS

Do najważniejszych produktów, które mają co najmniej $2 \%$ udziału w polskim eksporcie (a często również w imporcie), należy pięć kategorii sklasyfikowanych na czterocyfrowym poziomie agregacji $\mathrm{CN}$ :

29 Poniższa analiza struktury towarowej przeprowadzona została na podstawie danych GUS: Obroty ogółem, wedle klasyfikacji towarowej CN. Dane zaczerpnięte z interaktywnej platformy analitycznej SWAiD za lata 2004-2016. Zob. Obroty ogółem - wyszczególnienie wedlug nomenklatury towarowej, „SWAiD” [online, dostęp: 28.11.2018], dostępna w internecie: <http://swaid.stat.gov.pl/HandelZagraniczny_dashboards/Raporty_konstruowane/RAP_SWAID_HZ_3_4.aspx>.

30 Ze względu na globalne łańcuchy wartości często wiąże się to ze znacznym udziałem $\mathrm{w}$ imporcie. 
- aparatura odbiorcza dla telewizji, nawet zawierająca odbiorniki radiowe, lub aparatura do zapisu lub odtwarzania dźwięku lub obrazu; monitory i projektory wideo ( $2 \%$ eksportu, $1 \%$ importu);

- samochody i pozostałe pojazdy silnikowe przeznaczone do przewozu osób inne niż objęte pozycją 8702, włącznie z samochodami osobowo-towarowymi i wyścigowymi (4\%, 4\%);

- części i akcesoria do pojazdów samochodowych objętych pozycjami od 8701 do 8705 (6\%, 4\%);

- meble do siedzenia bez objętych pozycją 9402, w tym również te przekształcalne w miejsca do spania, oraz ich części (3\%, 1\%);

- meble inne niż w pozycjach 9401 i 9402 i ich części (2\%, 0\%).

Najważniejszymi towarami importowymi (niewymienionymi powyżej ze względu na niższy udział w eksporcie) były w 2016 r. oleje ropy naftowej i oleje otrzymywane z minerałów bitumicznych ( $0 \%$ eksportu, $4 \%$ importu) oraz leki z wyłączeniem wyrobów z pozycji 3002, 3005 lub 3006 $(1 \%, 2 \%)$.

W latach 2004-2016 nie doszło do znaczących zmian w strukturze towarowej polskiego eksportu i importu ${ }^{31}$. Spośród kategorii, które zachowały istotne miejsce w obrocie towarowym, największe zmiany dotyczą czterech najszerszych. Spadek udziału w łącznym handlu dotknął przede wszystkim metali nieszlachetnych (w eksporcie z 13\% do 9\%), produktów mineralnych (w eksporcie z $6 \%$ do $3 \%$, w imporcie z $10 \%$ do $7 \%$ ), pojazdów i statków powietrznych (w eksporcie z 17\% do 15\%, w imporcie z 14\% do 12\%). Najwyraźniej wzrósł w eksporcie udział maszyn i urządzeń mechanicznych (z 22\% do 25\%), zwierząt żywych (z 3\% do 4\%), gotowych artykułów spożywczych (z 4\% do $6 \%$ ) oraz produktów przemysłu chemicznego (z 5\% do 7\%).

Badając strukturę towarową handlu według klasyfikacji zaawansowania technologicznego, należy spostrzec pozytywne zmiany, tzn. wzrost udziału importu i eksportu towarów zaawansowanych technologicznie w łącznej wymianie handlowej Polski. Jednocześnie jednak powyższa analiza pokazuje, że zmiany te podlegały znacznym wahaniom. Wedle badań agregujących towary zgodnie z terminologią OECD i sekcją SITC dynamika wzrostu wartości polskich dostaw tych wyrobów przekraczała $150 \%$, choć wciąż wynika to ze stosunkowo niskiej bazy ${ }^{32}$. Badania wykazały ponadto - i potwierdzają to przytoczone wyżej

31 Potwierdzają to badania Mariusza-Jana Radły: M.-J. Radło, Przewagi konkurencyjne Polski $w$ handlu zagranicznym oraz bilans płatniczy w latach 2010-2015, [w:] Polska. Raport o konkurencyjności 2016, red. M.A. Weresa, Warszawa 2016, s. 81-85.

32 A. Szypulewska-Porczyńska, Rozwój..., s. 128-129. 
dane - że szczególnie pozytywnie integracja Polski z UE wpłynęła na handel produktami z branż samochodowej i spożywczej, do czego przyczyniła się m.in. wspólna polityka rolna ${ }^{33}$.

W handlu usługowym zdecydowanie dominują dwie kategorie - transport i podróże, i to zarówno w imporcie, jak i eksporcie. Trzecim segmentem odgrywającym tu istotną rolę są pozostałe usługi gospodarcze, z których największe znaczenie mają usługi prawne, księgowe oraz doradztwo w zakresie zarządzania i public relations ${ }^{34}$. W latach 2012-2016 (w których roczniki statystyczne wyszczególniają usługi według klasyfikacji EBOPS) doszło do spadku udziału dwóch najważniejszych typów usług, co może świadczyć o wzroście znaczenia ich bardziej skomplikowanych form. Jeśli chodzi o dostarczane przez Polskę usługi transportowe, to ich udział w handlu zagranicznym spadł z 29,5\% w 2012 r. do 27,1\% w 2016, a udział podróży - z 28,8\% do 22\%. Udział usług transportowych w imporcie zmniejszył się z $22,1 \%$ do $22 \%$, a podróży z 27,5\% do $23,3 \%$. W tym samym czasie z $7,8 \%$ do $10,7 \%$ wzrosło znaczenie eksportowanych przez Polskę usług informatycznych i telekomunikacyjnych, a importowanych - z 8,1\% do 9,2\%. Z 6,6\% do 7,7\% wzrósł udział dostarczanych poza granice usług prawych, doradztwa księgowego i w zakresie zarządzania i public relations, a z $8 \%$ do $11,2 \%$ - nabywanych ${ }^{35}$.

\section{Podsumowanie}

Z przedstawionej powyżej historii ostatnich stu lat polskiego handlu zagranicznego wyłania się obraz skromnych możliwości jego rozwoju. W dwudziestoleciu międzywojennym dopiero w $1923 \mathrm{r}$. stworzono warunki pozwalające na zwiększanie obrotów, ale niemożliwe było prowadzenie wymiany z najważniejszymi sąsiadami - z jednej strony z ZSRR, a z drugiej z Niemcami, które już w 1926 r. weszły na ścieżkę wojny celnej z Polską. Wielki kryzys natomiast de facto unicestwił jakiekolwiek możliwości rozwoju handlu zagranicznego. Przyczynił się do tego, że w 1938 r. wartość obrotów była niższa niż w 1922.

33 K. Śledziewska, Znaczenie wspólnej polityki handlowej UE dla państw Grupy Wyszehradzkiej, [w:] Handel międzynarodowy w rozwoju społeczno-ekonomicznym państw, red. S. Wydymus, M. Maciejewski, Warszawa 2016, s. 26.

34 Analiza struktury rzeczowej handlu usługowego na podstawie danych „Rocznika Statystycznego Handlu Zagranicznego" GUS z 2013 i 2017 r.

35 E. Czarny, A. Kuźnar, K. Śledziewska, Na ile innowacyjny jest eksport usług z Polski?, „Kwartalnik Kolegium Ekonomiczno-Społecznego »Studia i Prace«” 2017, nr 2 (30), s. $133-146$. 
W 1945 r. polska gospodarka, a co za tym idzie handel zagraniczny, ponownie zaczynała praktycznie od zera. Ład międzynarodowy oraz ustanowiony nad Wisłą ustrój gospodarczy uniemożliwiły dynamiczny rozwój wymiany towarowej z zagranicą. Mimo to już wówczas polska gospodarka wykazywała możliwości wzrostu wolumenu handlowego - również w handlu z państwami spoza bloku wschodniego. Chociaż transformacja ustrojowa na przełomie lat osiemdziesiątych i dziewięćdziesiątych oznaczała właściwie trzeci przypadek w XX w., gdy polska gospodarka - a zwłaszcza wymiana handlowa $\mathrm{z}$ zagranicą - rodziła się na nowo, to jednak tym razem proces odbudowy przebiegał zupełnie inaczej. Otwarcie się na sąsiadów i najważniejszych partnerów gospodarczych oraz napływ inwestycji zagranicznych doprowadziły do znaczącego rozwoju handlu zagranicznego, czego efektem był ponad czterokrotny wzrost polskiego eksportu w latach 1989-2004. Akcesja do UE w 2004 r. pozwoliła na utrzymanie tej dynamiki i w ciągu kolejnych dwunastu lat Polski eksport wzrósł ponad dwukrotnie.

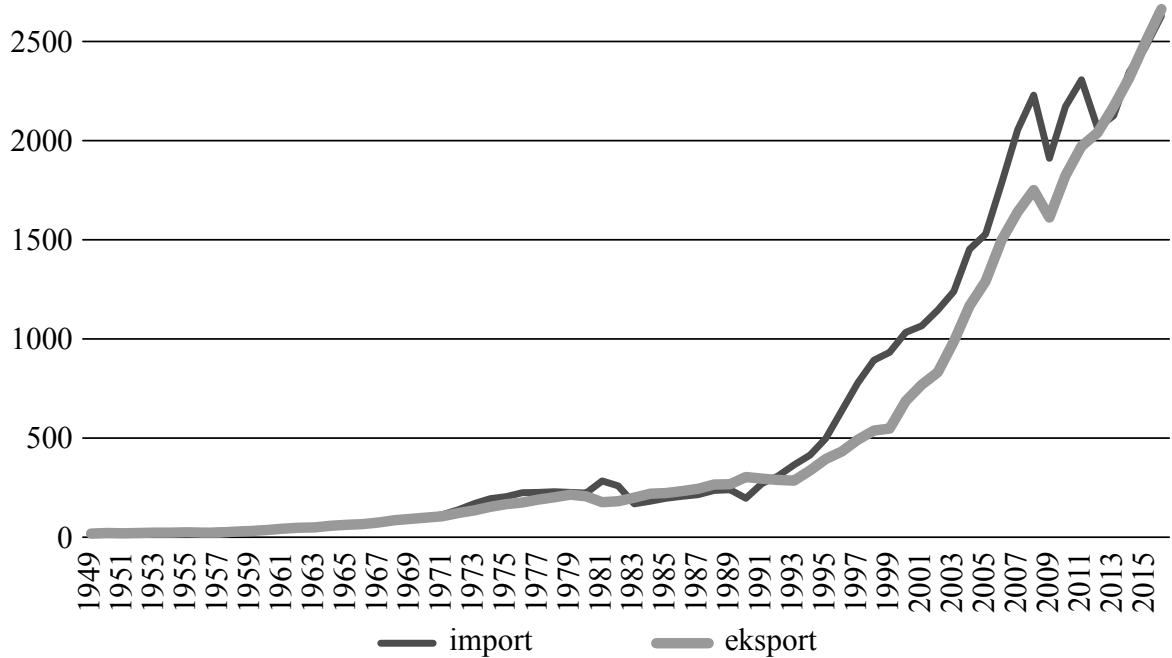

Wykres 3. Dynamika obrotów handlowych w cenach stałych za lata 1949-2016 (1970 r. = 100)

Źródło: oprac. własne na podstawie danych GUS

Warto zwrócić uwagę, że w ostatnich stu latach polskiego handlu zagranicznego dodatni bilans notowano głównie w okresach złej koniunktury. W latach 1922-2016 dodatnie saldo udawało się osiągnąc średnio rzadziej niż raz 
na trzy lata. W dwudziestoleciu międzywojennym był to czas wojny celnej z Niemcami i wielkiego kryzysu, w PRL natomiast pojedyncze lata, np. 1959, 1968, 1971 oraz lata osiemdziesiąte. Wyjątkowe były lata 1989 i 1990, kiedy Polska zanotowała dodatni bilans, korzystając z szoku transformacyjnego; przez kolejnych 25 lat III Rzeczypospolitej ani razu nie wyszła jednak z deficytu. W latach 2004-2016 większa dynamika wzrostu eksportu niż importu doprowadziła do historycznego, bo niezwiązanego z likwidacją bądź załamaniem się gospodarki, dodatniego bilansu handlowego Polski w 2015 r. oraz powiększenia go w 2016 r. W latach 2004-2016 saldo obrotów towarowych wzrosło z $-54 \mathrm{mld}$ do $+17 \mathrm{mld}$ zł, czyli o $71 \mathrm{mld}$. Polska stale poprawiała swój bilans, a w największym stopniu przyczynił się do tego handel z krajami UE (dodatni od 2009 r.). Co ciekawe, w wymianie towarowej $\mathrm{z}$ wieloma partnerami pogłębiała się nierównowaga - zarówno w przypadku nadwyżek, jak i deficytów ${ }^{36}$.

Tabela 2. Saldo handlowe Polski w latach 1922-2016

\begin{tabular}{|l|c|c|}
\hline \multicolumn{1}{|c|}{ Okres } & $\begin{array}{c}\text { Liczba lat z dodatnim } \\
\text { saldem handlowym }\end{array}$ & $\begin{array}{c}\text { Udzial lat } \\
\text { z dodatnim bilansem }\end{array}$ \\
\hline $1922-1938$ & 9 & $53 \%$ \\
\hline $1945-1988$ & 14 & $32 \%$ \\
\hline $1989-2003$ & 2 & $13 \%$ \\
\hline $2004-2016$ & 2 & $15 \%$ \\
\hline $\begin{array}{l}\text { Lącznie (lata 1922-1938 oraz } \\
\text { 1945-2016) }\end{array}$ & 27 & $30 \%$ \\
\hline
\end{tabular}

Źródło: oprac. własne na podstawie danych GUS

Dotychczasowe badania wskazują, że w latach 2004-2013 „Polska skutecznie wykorzystywała przewagi komparatywne w produkcji środków transportu, ich części i akcesoriów oraz towarów konsumpcyjnych trwałego użytku”37. Jednocześnie grupa przetworzonych artykułów spożywczych odnotowuje stały wzrost udziału w polskim eksporcie, co wskazuje na coraz lepsze zagospodarowanie potencjału sektorów rolno-spożywczych w polskim eksporcie do UE, choć wciąż tkwią w nich spore rezerwy rozwoju ${ }^{38}$.

36 E. Czarny, K. Śledziewska, Struktura geograficzna i rzeczowa polskiego handlu z zagranica po dziesięciu latach członkostwa w UE, [w:] Polska. Raport o konkurencyjności. Dekada członkostwa Polski w Unii Europejskiej, red. M.A. Weresa, Warszawa 2014, s. 100; A. Szypulewska-Porczyńska, Rozwój..., s. 126.

37 E. Czarny, K. Śledziewska, Struktura..., s. 116.

38 Tamże. 
Historia ostatnich stu lat polskiego handlu zagranicznego pokazuje, jak silnie jego rozwój uzależniony jest od wewnętrznych i zewnętrznych realiów politycznych. Działania państwa sprzyjające rozwojowi przedsiębiorstw i liberalizacja handlu z istotnymi partnerami znacząco wspomagają wzrost obrotów, a członkostwo w UE jak nigdy dotąd w ostatnim stuleciu ustabilizowało warunki prowadzenia wymiany z najważniejszymi sąsiadami. Umożliwiło to także powolne zmiany w strukturze towarowej w kierunku produktów bardziej zaawansowanych technologicznie. Jednocześnie, podczas gdy w czasie ostatniego kryzysu finansowego zahamował import, na ścieżkę wzrostu po roku powrócił eksport. Inaczej niż w II Rzeczypospolitej stabilność relacji z partnerami oraz silne powiązania międzynarodowe firm pozwoliły teraz Polsce uniknąć spadku obrotów handlowych.

\section{Bibliografia}

100 lat Polski w liczbach. 1918-2018, Warszawa 2018.

Czarny E., Kuźnar A., Śledziewska K., Na ile innowacyjny jest eksport ustug z Polski?, „Kwartalnik Kolegium Ekonomiczno-Społecznego »Studia i Prace«” 2017, nr 2 (30).

Czarny E., Śledziewska K., Struktura geograficzna i rzeczowa polskiego handlu z zagranica po dziesięciu latach członkostwa w UE, [w:] Polska. Raport o konkurencyjności. Dekada czlonkostwa Polski w Unii Europejskiej, Warszawa 2014.

Handel międzynarodowy $w$ rozwoju społeczno-ekonomicznym państw, red. S. Wydymus, M. Maciejewski, Warszawa 2016.

Jasiński L.J., Bliżej centrum czy na peryferiach? Polskie kontakty gospodarcze z zagranica w XX wieku, Warszawa 2011.

Kaliński J., Gospodarka w PRL, Warszawa 2012.

Kaliński J., Transformacja gospodarki polskiej w latach 1989-2004, Warszawa 2009.

Kłosiński K., Rozumowska-Gapeeva T., Międzynarodowy obrót ustugowy Polski (2004-2007), [w:] Polska $w$ handlu międzynarodowym. Materiaty z konferencji naukowej z okazji 70. rocznicy urodzin profesora Pawła Bożyka, red. J. Misala, Warszawa 2011.

Landau Z., Tomaszewski J., Trudna niepodległość. Rozważania o gospodarce Polski 1918-1939, Warszawa 1968.

Landau Z., Tomaszewski J., Zarys historii gospodarczej Polski 1918-1939, Warszawa 1960.

Obroty ogótem - wyszczególnienie wedlug nomenklatury towarowej, „SWAiD” [online, dostęp: 28.11.2018], dostępny w internecie: <http://swaid.stat.gov.pl/HandelZagraniczny_ dashboards/Raporty_konstruowane/RAP_SWAID_HZ_3_4.aspx>.

Polska. Raport o konkurencyjności 2016, red. M. A. Weresa, Warszawa 2016.

Polska. Raport o konkurencyjności. Dekada członkostwa Polski w Unii Europejskiej, red. M.A. Weresa, Warszawa 2014.

Polska $w$ handlu międzynarodowym. Materiaty z konferencji naukowej z okazji 70. rocznicy urodzin profesora Pawła Bożyka, red. J. Misala, Warszawa 2011.

Radło M.-J., Przewagi konkurencyjne Polski w handlu zagranicznym oraz bilans płatniczy w latach 2010-2015, [w:] Polska. Raport o konkurencyjności 2016, red. M.A. Weresa, Warszawa 2016. 
Szypulewska-Porczyńska A., Rozwój handlu zagranicznego Polski po wstapieniu do Unii Europejskiej, [w:] Wybrane aspekty funkcjonowania Polski w Unii Europejskiej. Bilans dziesięciu lat członkostwa, red. G. Wojtkowska-Łodej, H. Bąk, Warszawa 2014.

Śledziewska K., Znaczenie wspólnej polityki handlowej UE dla państw Grupy Wyszehradzkiej, [w:] Handel międzynarodowy w rozwoju społeczno-ekonomicznym państw, red. S. Wydymus, M. Maciejewski, Warszawa 2016.

Wybrane aspekty funkcjonowania Polski w Unii Europejskiej. Bilans dziesięciu lat członkostwa, red. G. Wojtkowska-Łodej, H. Bąk, Warszawa 2014.

Zarys historii Polski w liczbach. Społeczeństwo, gospodarka, oprac. C. Kuklo, J. Łukasiewicz, C. Leszczyńska, Warszawa 2012. 